\title{
ERRATUM
}

Anna Karawajczyk · Francesco Buda

\section{The metal bonding domain of the antitumor drug Fe(II)-bleomycin: a DFT investigation}

Published online: 12 February 2005

(C) SBIC 2005

\section{J Biol Inorg Chem (2005) 10:33-40}

Fig. 1: The structure of bleomycin $\mathrm{A}_{2}, \mathrm{~B}_{2}$, and pepleomycin given was incorrect and is reproduced correctly here.

Fig. 1 The structure of bleomycin $\mathrm{A}_{2}, \mathrm{~B}_{2}$, and pepleomycin. The numbers 1-7 indicate the possible coordination sites to the metal. The loop shows the PMAH ligand $(2-\{[N-$ (aminoethyl) amino]methyl $\}-4-\{N-[2-(4-$ imidazolyl)ethyl]carbamoyl $\}$ 5-bromopyrimidine) [5]

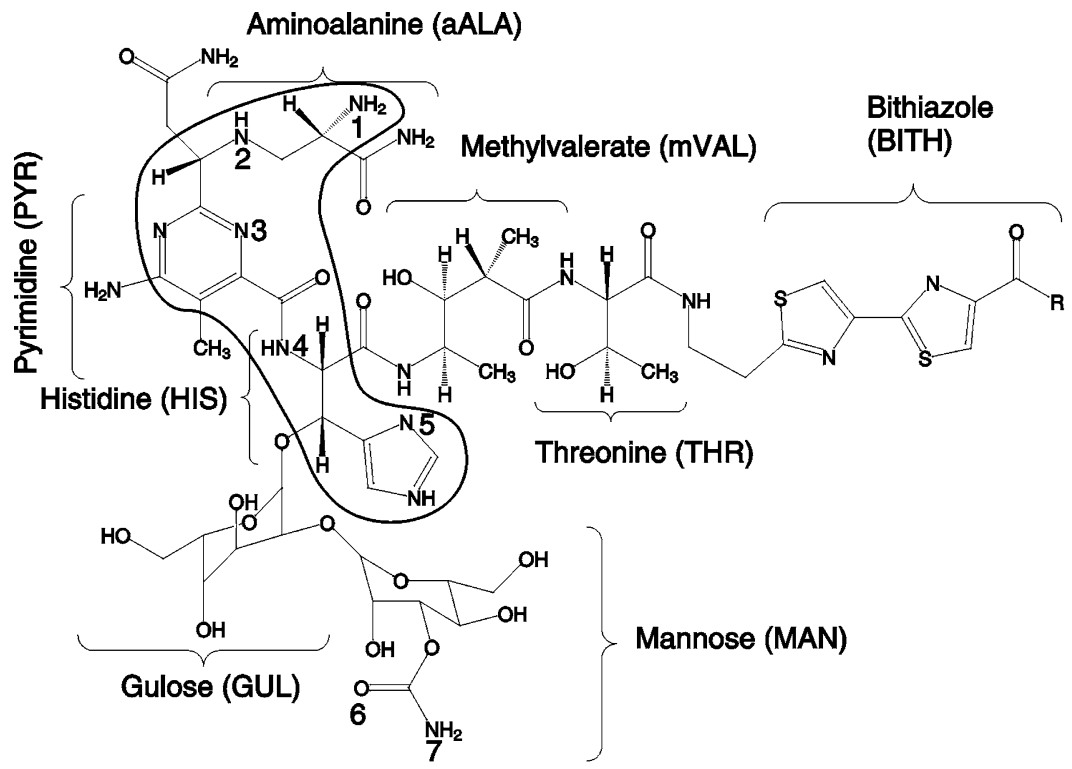

$$
\begin{array}{ccc}
\text { Bleomycin } & \mathrm{A}_{2} & \mathrm{R}=-\mathrm{NH}\left(\mathrm{CH}_{2}\right)_{3} \mathrm{~S}^{+}\left(\mathrm{CH}_{2}\right)_{3} \\
\mathrm{~B}_{2} & \mathrm{R}=-\mathrm{NH}\left(\mathrm{CH}_{2}\right)_{4} \mathrm{NHC}(\mathrm{NH})\left(\mathrm{NH}_{2}\right) \\
\text { Peplomycin } & \mathrm{R}=-\mathrm{NH}\left(\mathrm{CH}_{2}\right)_{3} \mathrm{NHCH}\left(\mathrm{CH}_{3}\right) \mathrm{Ph}
\end{array}
$$

The online version of the original article can be found at http:// dx.doi.org/10.1007/s00775-004-0610-8

A. Karawajczyk $\cdot$ F. Buda $(\square)$ Leiden Institute of Chemistry, Gorlaeus Laboratories, 2300 RA Leiden, The Netherlands

E-mail: f.buda@chem.leidenuniv.nl Fax: + 31-71-5274603 